Nevşehir Bilim ve Teknoloji Dergisi Cilt 6(Kapadokya Ulusal Bağcılık Çalıştayı Özel Sayı) 137-148 2017

DOI: 10.17100/nevbiltek.288316

URL: http://dx.doi.org/10.17100/nevbiltek.288316

\title{
Bağdan Sofraya Yemeklik Asma Yaprak Üretimi
}

\author{
Rüstem CANGI ${ }^{1 *}$, Adem YAĞCI ${ }^{1}$ \\ ${ }^{1}$ Gaziosmanpaşa Üniversitesi, Ziraat Fakültesi, Bahçe Bitkileri Bölümü, Tokat
}

$\ddot{O z}$

Bağcılık dünyada en temel tarımsal faaliyet kollarından birisidir. Türkiye’de bağlardan hem üzüm hem de asma (V.vinifera) yaprakları yoğun olarak üretilmekte ve tüketilmektedir. Salamuralık asma yaprakları (dolma) Akdeniz diyetlerinde yaygın olarak sevilen bir Türk yemeğidir. Asma yaprağı bol miktarda vitamin, diyet lifi ve mineral içerir. Asma yaprakları hem taze hem de salamura şeklinde kullanılabilir. Yaprak sarması için genç yapraklar tercih edilmektedir. Salamura asma yaprağı üretimi için Narince, Sultani Çekirdeksiz, Yapıncak ve Emir üzüm çeşitleri daha uygundur. Salamura asma yaprağı üretimi ve tüketimi son yıllarda Türkiye'de sürekli olarak artmaktadır. Ayrıca son yıllarda hazır gıda sektörü ve batı ülkelerinde asma yaprağı dolmasına olan talep artmaktadır.

Anahtar Kelimeler: Asma, salamuralık asma yaprağı, hasat, ürün işleme

\section{Production of Grapevine Leaves From Vineyard to Table}

\section{Abstract}

Viticulture is one of the major agricultural branches in world. Both grape and vine ( $V$. vinifera) leaves in vineyard are intensely produced and consumed in Turkey. Brined grape vine leaves, dolma is a well-liked Turkish dish, common to Mediterranean diets. The vine leaf contains an abundant amount of vitamins, dietary fiber and minerals. Vine leaves can be used as both in fresh and stored forms. Young leaves are choosen for stuffed dish. Narince, Sultani Cekirdeksiz, Yapincak and Emir grape cultivars are more suitable for this purpose. Brined vine leaves production and consumption has continuously increased in Turkey recent years.

Keywords: Vine, brined vine leaves, harvest, processing

*e-mail: rustem.cangi@gop.edu.tr 


\section{Türkiye’de Salamuralık Asma Yaprağı Üretiminin Genel Durumu}

Bağcılık ülkemizin önemli tarım kollarından birisi olup, ülkemizde 2016 yılında 4352269 dekar bağ alanından 4 milyon ton yaş üzüm üretimi bunun en önemli göstergelerinden birisidir [1]. Bağc1lık, tarımla uğraşan çok sayıda üreticinin geçim kaynağı olduğu gibi, değişik değerlendirme şekilleriyle tarımsal ürünlerimiz içerisinde önemli yer tutmaktadır. Bağcılık aynı zamanda ulusal ekonomimize de büyük katk1 sağlayan ürünlerden bir tanesidir [2].

İnsan sağlığı ve beslenmesindeki öneminin yanı sıra, değerlendirme şekillerinin de çok yönlü oluşu üzümün değerini daha da artırmaktadır. Üzüm ülkemizde sofralık, kurutmalık ve şaraplık olarak tüketim şekillerinin dışında hiç bir ülkede görülemeyecek kadar farklı şekillerde değerlendirilmektedir. Bunlara üzüm suyu, rakı, hardaliye, sirke, turşu, koruk suyu, koruk turşusu, saruç, papara, pepeçura, pekmez, gün balı, köme, köpüklü orcik, üzüm köftesi, üzüm peltesi, bulama, çek çek, köfter, kesme, tarhana, dilme, pestil, bastık, çullama, muska örnek olarak sayılabilir.

Anadolu insanı üzümden çok farklı şekillerde faydalanan asmanın yapraklarından da yararlanmayı düşünerek zekâ ve kültürlerinin yüksekliğini bir kez daha göstermiş ve mutfaklarına yeni bir ürün katarak zenginleştirmişlerdir. Ülkemizin hemen her yöresinde düğün, bayram ve Hıdırellez gibi özel günlerinde hazırlanan yemeklerin başında yaprak sarması gelir. Asma yaprağı dolma, cevizli bat, asma cacı̆̆ı, pide iç harcı yapımı yanında ekstraktı da geleneksel tıpta kullanılmaktadır. Yine asmanın taze sülük ve filizleri de son zamanlarda ticari olarak turşu yapımında kullanılmakta ve piyasada satılmaktadır [3 ve 4]. Sarma ve dolma geleneksel Osmanlı coğrafyası mutfağını temsil eden önemli yemeklerdendir. Üzüm yaprağından yapılan sarma saray ve konaklarda ana yemek yanında garnitür olarak en az 4 yüzyıldan beri tüketilmektedir [5 ve 6]. Günümüzde değişik şekillerde hazırlanan sarma yemeği, Türkiye, Yunanistan, Ermenistan, İran, Arap ülkeleri ile Balkanlarda hala yoğun olarak tüketilmektedir. Turistik tesislerde yabancı turistlerin zeytinyağlı sarmayla tanışması, hazır yemek sektöründeki gelişmeler son yıllarda bu ürünün tüketimindeki artışında önemli rol oynamıştır.

Asma yaprağı, gövdenin yanal organlarından birisi olup, yapraklar özümleme ile yükümlüdür. Esas görevi fotosentez ve terleme olduğundan bu göreve uygun geniş bir yüzeye sahiptir. Fotosentez ürünleri gün içerisinde yapraktan tümüyle taşınamadıklarından besin değeri yönünden de önemli organ olarak değer taşımaktadır [7 ve 8]. Yeni oluşmuş yaprak; yaprak ayası, yaprak sapı ve yaprak sapına bağlı bir çift yaprakçıktan oluşur. Beşli damarlanma asma yaprağının karakteristiğini verir. Yaprakların büyüklüğü, rengi ve şekli çeşide, büyüme şartlarına ve yaprağın sürgün üzerindeki yerine göre değişmektedir [9]. Asma yaprağının rengi açık yeşil, sarı-yeşil, koyu yeşil veya kırmızımsı olabilmektedir. Asma yaprağının bileşiminde şekerler, organik asitler, amino asitler, fenolik bileşikler ve bazı vitaminler bulunmaktadır [10].

Asma yaprağı düşük kalorili, yüksek miktarda diyet lif, kalsiyum, fosfor, fenolik bileşik, K1 ve C vitamini açısından oldukça zengindir. Çok zengin bir mutfak kültürüne sahip ülkemiz insanı, asma yaprağından zeytinyağı sarma, etli dolma, baklalı dolma, ekşili dolma yapmaktadır. Bir araştırmada $100 \mathrm{~g}$ zeytinyağlı asma yaprağ sarmasında; 2,68 g protein, 11,19 g yağ, 3,80 g CHO, 21,68 mg kalsiyum, 341 mg sodyum, 1,90 g C vitamini bulunduğu bildirilmiştir[11].

Ülkemizin hemen her bölgesinde asma yaprağı geleneksel olarak uzun yıllardan beri tüketilmektedir. Bağ veya bahçelerinde üzüm yetiştiren vatandaşlarımız, asmalardan topladıkları 
yaprakları ev ihtiyaçlarını karşılamak veya gelir elde etmek amacıyla değerlendirmektedir. 1990’lı yılların sonlarından beri, salamuralık asma yaprak üretimi, tüketimi ve ticaretinde bir artış dikkat çekmektedir. Bu artışta turizm sektörü, hazır yemek ve catering sektöründeki gelişmeler ile yöresel mutfak sektörünün ticari boyut kazanmasının etkisi büyük olmuştur. Ayrıca, üretici açısından bakıldığında asma yaprağı üretimi, aile işletmeciliğine uygun bir üretim dalı olması, üzüm yetiştiriciliğine göre bakım ve masrafının düşük olması, birim alandan getirisinin yüksek olması, ticari açıdan oldukça karlı bir sektör haline gelmesini sağlamıştır. 2015 yılı Mart ayında Manisa'da don zararı görülen bağlarda salamuralık yaprak toplayan üreticiler, ekonomik anlamda zararlarının bir nebze de olsa karşılayabilmişlerdir [12]. Üzüm yetiştiriciliğinde ekolojinin üzümün olgunlaşması için yeterli olmadığı yerlerde asma yaprak üretiminin mümkün olması, bu üretim şeklini kırsal kalkınma açısından da dikkate almaya değer kılmaktadır [13].

Sarmalık asma yaprağına karşı yoğun ilgi, son yıllarda yalnızca yaprak üretimine yönelik yeni bir bağcılık sistemini zorlamaktadır. Halen, üzüm üretimi ile bir arada yürümesine rağmen, özellikle Tokat yöresi bağlarında yaprağın üzüme tercih edildiği, yaprak verimini artırmak için asmalar kısa budanmakta, sulama ve azotlu gübreleme yapılarak daha kuvvetli vejetatif gelişmeye zorlanmaktadır. Ege Bölgesi'nde ise, iklim daha elverişli ve Sultani Çekirdeksiz zaten kuvvetli gelişen bir çeşit olduğu için, zamanında ve bilinçli yapılan yaprak alma, gelişmenin dengelenmesine katkı sağlayabilmektedir [14].

İlkbaharda sürgünlerin henüz taze olduğu dönemlerde toplanan asma yaprakları, hem taze hem de salamura yapılarak sarma yapımında değerlendirilmektedir. Ülkemizde yetiştiriciliği yapılmakta olan birçok üzüm çeşidinin yaprakları salamura ya da konserveye işlenerek değerlendirilmektedir.

Şekil, kalınlık, tüylülük, dilimlilik gibi kriterler bakımından üzüm çeşitleri çok farklı özellikler gösteren yapraklara sahiptirler. $\mathrm{Bu}$ nedenle her çeşidin yaprakları konserve yapımında kullanılmamaktadır. Kalın, tüylü ve fazla dilimli yapraklar tüketiciler tarafından beğenilmediklerinden bu tip yapraklar tercih edilmemektedir. Sarmalık yaprak üretimi için ince, tüysüz, ince damarlı, mümkün olduğunca dilimsiz ve damakta ekşimsi bir tat bırakan çeşitler tercih edilmektedir. Bu nitelik ve üretim miktarı ile en fazla salamuraya işlenen sarmalık çeşitlerimiz Sultani Çekirdeksiz ve Narince çeşitleridir. 41 B anacına ait yaprakların da, bu amaçla kullanılabileceği bildirilmiştir [15].

Özellikle son y1llarda Ege Bölgesi ve Tokat yöresi başta olmak üzere yaprak üretimini amaçlayan çok sık dikim sistemlerinin uygulandığı yeni bağlar kurulmakta, hatta bazı tesislerde üzüm geliri ikinci plana atılmaktadır [16]. Sultani Çekirdeksiz çeşidinden sarmalık yaprak üretimi, Ege Bölgesi için önemli bir ek gelir kaynağıdır. Tokat bölgesinde eski bağ alanlarında, asmaların dikim mesafeleri çok dar olup, dekardaki asma sayısı normalin çok üzerindedir. Bu durum, yöredeki salamuralık asma yaprağı üretiminin üzüm üretimi kadar önem taşımasındandır. Tokat yöresinde de bağlardan yılda 10000 ton civarında yaprak toplanmaktadır. Hatta bu yörenin en önemli şaraplık ve şıralık üzüm çeşidi olan Narince'nin, daha çok yaprakları için yetiştirildiği bile söylenebilir. Erbaa Ticaret ve Sanayi Odası 2016 yılında Türk Patent Enstitüsüne Narince bağ yaprağı için coğrafi işaret almak üzere başvuruda bulunmuştur. Bunların yanı sıra, Trakya'da özellikle Tekirdağ ilinde yetiştirilen Yapıncak, Nevşehir'de Emir çeşidinin yaprakları da yaygın olarak bu amaçla değerlendirilmektedir. Son zamanlarda Mersin, Amasya, Kilis, Gaziantep, Konya ve Denizli gibi illerde de bağ alanlarında salamuralık yapraktan ticari olarak yararlanılmaktadır [15, 17, 18,19, 20, 21 ]. Tokat ilinde bazı asma fidan üreticilerinin, fidanlık 
parsellerindeki fidanlardan topladıkları yaprakları ticari olarak değerlendirmektedir. Asma yaprağının üzüm gibi ekonomik getirisi olmasına rağmen ne sebze ne de başka bir bitkisel ürün grubu içerisinde TUİK'in istatistiki verilerinde yer almamaktadır. İhracatçılar birlikleri tarafından yayınlanan raporlar bu konuda bizlere bilgi vermektedir. Sadece Tokat ilinde 50 milyon TL den fazla yıllık getirisi olan bir ürün için bir an önce BUGEM tarafından TUİK verilerinde yer alması için girişimde bulunması gerekmektedir [22].

Salamuralık asma yaprağı üretim ve pazarlamasında pestisit kalıntısı en önemli sorundur. Ticari üzüm yetiştiriciliğinde hastalık ve zararlılarla yoğun mücadele yetiştiricilikte en önemli kültürel işlemlerin başında gelmektedir. Salamuralık asma yaprakları, aynı zamanda üzüm üretiminin yapıldığı asmalardan hasat edilmektedir. Asma yapraklarının normal döneminde (Mayıs-Haziran) hasatların gerçekleştirildiği periyotta, bağlarda genellikle külleme, mildiyö ve ölü kol hastalıklarına karşı değişik kontakt veya sistemik etkili fungisit ve akarisitler kullanılmaktadır. Son yıllarda asma yaprakları Ağustos ayına kadar toplanmaktadır. Bu dönemde uygulanan insektisit uygulamaları nedeniyle artık insektisit etkili maddesine sahip kalıntılar da yapraklar içerisinde görülebilmektedir. Meyve ve yaprak üretimine yönelik yetiştiricilik şeklinde, üzüm kalitesi düşebilmekte ve yapraklarda pestisit kalıntısı gibi ciddi sorunlara da yol açabilmektedir. Ülkemizde salamuralık asma yaprağında pestisit kalıntısı ile ilgili bildiri ve araştırma sayısı son derece sınırlıdır [23, 24, 25, 26, 27]. Bu durumun ne kadar vahim olduğu ihracat ürünlerinde yapılan analiz sonuçlarında görülmektedir. 2015 yılı içerisinde AB ye (İsveç) ihraç etmek üzere gönderilen ve sınırda kalıntı analizleri yapılan asma yapraklarında saptanan pestisitler ve kalıntı miktarları Çizelge 1' de sunulmuştur [28].

Tablo 1. AB'ye 2015 yılında ihraç edilecek asma yapraklarında saptanan pestisit etken madde ve kalıntı miktarları

\begin{tabular}{lll}
\hline Fenbutatin Oxide (5.4 Ppm) & Penconazole $(0.063 \mathrm{Ppm})$ & Carbendazim $(0.24 \mathrm{Ppm})$ \\
Boscalid (0.5ppm) & Dimethomorph $(0.06 \mathrm{Ppm})$ & Tebuconazole $(0.18 \mathrm{Ppm})$ \\
Azoxystrobin $(0.50 \mathrm{Ppm})$ & Fluopyram $(0.058 \mathrm{Ppm})$ & Carbaryl $(0.019 \mathrm{Ppm})$ \\
Chlorpyrifos $(0.44 \mathrm{Ppm})$ & Tetraconazole $(0.052 \mathrm{Ppm})$ & Emamectin $(0.016 \mathrm{Ppm})$ \\
İprodione $(0.290 \mathrm{Ppm})$ & Kresoxim(0.05 Ppm) & Acetamiprid $(0.016 \mathrm{Ppm})$ \\
Difenoconazole $(0.073 \mathrm{Ppm})$ & Pyraclostrobin $(0.05 \mathrm{Ppm})$ & İndoxacarb $(0.15 \mathrm{Ppm})$ \\
& & Esfenvalerate $(0.12 \mathrm{Ppm})$
\end{tabular}

Ülkemiz menşeli asma yaprağının Avrupa Birliği (AB) ülkelerine ihracatında fiziksel ve kimlik kontrol sıklığının 1 Ocak 2015 tarihi itibarıyla \%20 olarak tatbik edileceğinin daha önce duyurulduğu; ancak 27 Haziran 2015 tarihli AB Resmi Gazetesi'nde yayımlanan Komisyon Yönetmeliği uyarınca bahse konu oranın 1 Temmuz 2015 tarihi itibarıyla \%50 yükseltileceğinin öngörüldüğü hususuna değinilmiştir [29]. Alınan kararlardan, ihraç edeceğimiz asma yapraklarında gıda güvenliği açısından denetim ve kontrollerin daha yoğun olarak gerçekleştirileceği anlaşılmaktadır.

Türkiye'nin asma yaprak ihracatından yaklaşık 13,5 milyon dolar, yapraktan üretilen sarma ve dolmadan ise 135 milyon dolar ihracat geliri elde edildiği bildirilmektedir [30]. Ülkemizde üretilen sarmanın kuş üzümü ve fıstığıyla daha sofistike olması bir avantajdır. Ülke tanıtımında önemli bir stratejik bir ürün olan asma yaprağındaki pestisit kalıntısı nedeniyle Avrupa’ya ihracatta gerileme olduğu, bu boşluğu ise Yunanistan'ın doldurduğu bildirilmektedir. Yunanistan’ın el işçiliğinin düşük olması 
nedeniyle sarmaları Çin’de ürettirdiği bildirilmektedir [30]. Ülkemizde salamuralık asma yaprağının sürdürülebilir bir şekilde üretimi ve pazarlanabilmesi için, pestisit kalıntı sorununun çözülmesi şarttır.

Üzüm üretimine yönelik bağcılık için ekolojinin çok uygun olmadığı bölgelerin çoğunda asmalardan yaprak üretimi mümkündür. Bu tip yörelerde kırsal kalkınma kapsamında göçü önlemek ve aile işletmesi şeklinde getirisi yüksek olan salamuralık asma yaprak bağcılığı önerilmektedir [30]. Bu işletmelerde küçük alanda, düşük masraflı ve kısa zamanda asma yaprak getirisinin yüksek olması yanında, pestisit kalıntısı olmayan yaprak üretmek de daha kolay olacaktır. İhraç edilemeyen yapraklar veya analiz yapılmayan kalıntı içeren yapraklar, yurtiçinde tüketilmektedir. Asma yaprağı, toplumda her kes tarafından sevilerek tüketilen bir ürün olması nedeniyle, pestisit kalıntısının ülkemiz insanlarının sağlığını da ne kadar tehdit ettiği de açıkça ortadadır.

Bağlarda salamuralık asma yaprak üretiminde yaşanan sorunlardan bir tanesi de bazı yıllarda yaşanan dolu zararıdır. Tarsim henüz asma yaprağı ürününü sigorta kapsamına almamıştır. Ancak, salamuralık asma yaprağının dolu zararına karşı sigortalanmasına yönelik ekspertiz raporlarını oluşturmaya yönelik araştırmalar yapılmaktadır [31].

\section{Salamuralık Bağ Tesisi ve Yönetiminde Dikkat Edilecek Hususlar}

Anaç seçimi: Bağ tesis edilecek arazide toprağın aktif ve toplam kireç miktarı, pH'sı, toprağın tekstürü, tuz oranı, taban suyu seviyesi, toprak derinliği, taşl11ık durumu incelenerek uygun anaç seçimi yapılmalıdır. Yine bölgede yağış durumu dikkate alınarak, gerekirse kuraklığa dayanıklı anaç tercih etmek uygun olacaktır. Ekolojinin vejetasyon durumu da mutlaka göz önünde tutulmalıdır.

Çeşit seçimi: Yöreye has üzüm çeşidinin yaprakları ticari olarak salamuralık değeri varsa, ilk önce bu çeşit tercih edilmelidir. Yemeklik olarak tüketilecek asma yapraklarında; şekil, dilimlik, kalınlık, tüylülük durumu kadar, kısa sürede pişmesi de önemlidir. Az dilimli, az tüylü, ince, dilimsiz veya az dilimli yapraklara sahip çeşitler tercih edilir. Ekoloji Sultani Çekirdeksiz, Narince, Emir, Yapıncak, Tekirdağ Çekirdeksizi, Trakya İlkeren, Hamburg Misketi, Pafi vb sarma ve dolma yapımına uygun çeşitlerin yetişmesine uygun ise, bu çeşitlerde üretim amaçlı bağ tesisinde tercih edilebilir. Hatta 5BB, 41B ve SO4 anaçlarına ait yapraklar da sarma/dolmalık amaçla tüketime uygundur [15].

Fidan temini: Üreticilerin bağ kurarken ismine doğru fidan temin etmeleri uygun olacaktır. Kum oranı \%60 dan az olan yerlerde, aşılı fidan kullanılmalıdır. Kıraç alanlarda eğer sulama imkânı kısıtlı ise, Amerikan asma fidanını bağa diktikten sonra, yerinde aşılama ile bağ tesis edebilirler.

Dikim zamanı ve dikim sıklığı: İklimi sert geçen yerlerde ilkbahar dikimi, diğer bölgelerde geç sonbahardan ilkbahar başlarına kadar dikim yapılabilir. Salamuralık yaprak üretiminde telli sistemlerde sıra arası $3 \mathrm{~m}$, sıra üzeri 1,25-1,50 m olabilir. Arazi eğer traktörle işlenemeyecek kadar eğimli ise daha sık dikim yapılabilir. Goble terbiye şekillerinde ise 1.25 x 1.25 m dikim sıklığı kullanılabilir.

Dayanak sistemi ve asmaların terbiye edilmesi: Kısa budamaya ihtiyaç duyan salamuralık yaprak yetiştiriciliğinde çift kollu kordon veya goble sistem tercih edilebilir. Kordon sisteminde gövde yüksekliği en az $50 \mathrm{~cm}$ olmalıdır. Yazın sıcak olan yerlerde omca içinin çok açık olmamasında fayda görülmektedir. Dayanak sistemi olarak beton, ahşap veya metal materyallerden oluşan direkler kullanılabilir. Çift T sistemi bu yetiştiricilik için uygun bir sistemdir. 
Sulama: Yaprak üretimi yapılacak bağlarda Haziran ve Temmuz aylarında yeterli yağış olmadığı zaman ek sulama yapılmalıdır. Mümkünse damla sulama tercih edilmelidir. Aşırı sulamadan kaçınmak gerekir.

Verim budaması: Salamuralık yaprak üretiminde önerildiği şekilde kısa budama (1-2 göz) yapılmalıdır. Asmalarda bırakılacak göz sayısı asma yaşı ve gelişme gücü dikkate alınarak (10-25 göz/omca) gerçekleştirilmelidir [32].

Hastalık ve zararlılarla mücadele: Salamuralık yaprak hasat döneminde özellikle külleme, mildiyö hastalıkları ile bağ uyuzu zararlısı problemi sıkça yaşanabilmektedir. Bağlarda budama artıkları bağdan uzaklaştırılmalı, omcanın altı temiz tutulmalı, yere düşen enfekteli yapraklar toprak işlemesi yapılarak derine gömülmeli, çok iyi havalanma ve güneşlenme sağlanmalıdır. Dinlenme döneminde budamadan sonra asmalara \%2'lik bordo bulamacı uygulanmalıdır. Salamuralık yaprak üretiminde kesinlikle sistemik pestisit ve özellikle yaprak hasadı döneminde yaprak gübresi kullanmamalıdır. Sürgünler 25-30 cm iken yapılan ilaçlamadan yaklaşı 5-7 gün sonra ilk yaprak hasadı yapıllır. Her hasattan sonra koruyucu amaçlı sistemik olmayan kontakt etkili ilaçlama uygulamaları gerçekleştirilmelidir. Yaprak hasadı döneminde külleme ve bağ uyuzu için her yaprak hasadından sonra gülleci bulamacı uygulanabilir.

Salamuralık bağlarda bağ tesisinde yer/yöney seçimi, toprak hazırlı̆̆ı, fidan dikimi, dayanak sisteminin oluşturulması, dikim şekli, gübreleme, budama sanitasyonu, genç bağlarda bakım işleri ve gübreleme üzüm yetiştirilen bağlarda standart olarak uygulanan işlemlerdeki gibidir [33].

\section{Asmalarda Yaprak Hasadı}

Asma yaprağı üretiminin amaçlandığı bağlarda, budamada bırakılan kışlık gözlerden ortalama 10-20 adet yazlık sürgün gelişmekte olup, yapraklar bu sürgünlerden toplanmaktadır. Yaprak toplamaya yazlık sürgünler 60-70 cm uzunluğa eriştikleri dönemde çiçek salkımı taşımayan sürgünler üzerindeki yaprakların koparılmasıyla başlanır. Asmadaki üzümün kalitesinin bozulmaması için, bazaldan itibaren 4.-5. boğumlardan yaprak alınmamalıdır. Mayıs ortalarında başlayan bu işlem Ağustos başlarına kadar devam etmektedir. Salamuralık yaprak üretiminde yaprak toplarken, sürgünlerin sürmeye başlamasıyla, çiçeklenme öncesi (Mayıs ayı) ile ben düşme dönemi arasında, yazlık sürgünler üzerindeki uçtan itibaren olgun yaprağın $2 / 3$ büyüklüğüne erişen, 4. 5. ve 6. yapraklar toplanmalıdır (Şekil 1). Üreticiler kış veya ilkbahar geç donlarının bağlarda salkımlara zarar vermesi durumunda daha fazla yaprak toplamaktadırlar [16, 23, 32].

Özellikle yaprak toplanan dönemde bağlarda herbisit uygulaması yapılmamalıdır. Zira rüzgârla yapraklara gelecek kimyasallar üründe kalıntıya ve dolayısıyla gıda güvenliği açısından risk oluşturacaktır.

Yapraklar sabah erken vakitte kırılmalı, kısa sürede salamuraya işlemelidir. Zira yapraklar hasat sonrası yığın şeklinde bırakılırsa kızışma nedeniyle yapraklar zarar görecektir. Toplanan yaprakları iki boya ayırarak salamuraya işlemek, yaprakların pazar değerini artıracaktır. Hasat edilen yapraklarda hasarlı, şekil ve renk bozukluğu görülen yapraklar ayıklamalıdır. Yine hasat edilen yapraklarda çöp, böcek, ilaç ve toz gibi yabancı maddelerden arındırmak için yaprakların yıkanmasında fayda vardır. Bu işlem yaprakları desteleme sonrası desteleri dağıtmayacak şekilde yapılmalıdır [34]. 
Asmalardan tam erişmiş olgun, kart yapraklar toplanmamalıdır. Yaşlanmış asma yapraklarının salamuralık asma yaprağı üretiminde ve insanlarda beslenme olarak selüloz içeriği yönünden fakirdir. Besin içeriği olarak ve fotosentezde üretilen karbonhidrat miktarının yaşlı yapraklarda az olması, ayrıca yaşlı yaprakların sert bir yapıya sahip olması nedeniyle sarma veya dolma olarak değerlendirmek için uygun değildir (Şekil 2), [35].

Bağlarda don zararı nedeniyle çiçek salkımı az olduğu veya salkımlar zarar gördüğü zaman, bağlarda daha fazla yaprak toplanır. Yaprak hasadı yağış, hava sıcaklığı ve asmanın gelişme durumuna göre 7-12 gün arayla 4-8 kez hasat yapılabilmektedir. İlk dört hasat dönemindeki yapraklar daha çok zeytinyağlı sarma, daha sonraki dönemlerde yapraklar daha küçük olduğu için dolma yapımına uygundur. Bağdan üzüm ürününden gelir elde edilecekse, salkım etrafındaki 3-5 yaprağa dokunulmamalıdır. Aşırı yaprak toplama bağlarda üzümlerin kurumasına ve ürün kaybına yol açabildiği için, asmalardan aşırı yaprak toplanmamalıdır [37 ve 38].

Tokat ilinde yapılan çalışmalarda Narince çeşidinde dekardan 333-800 kg arasında yaprak toplandığg bildirilmektedir [16, 39,40]. Manisa bölgesinde çiçeklenme öncesi 1 defa ve 10 gün arayla ben düşmeye kadar dönemde dekardan $160 \mathrm{~kg}$ yaprak toplandığı bildirilmektedir. Manisa bölgesinde üreticilerin bu değerden daha fazla yaprak topladıkları da bir gerçektir. Konya'da yapılan çalışmada, serada Narince ve Sultani Çekirdeksiz üzüm çeşidinde, tepe alma işlemi yapılan bir yaşlı asma fidanlarına $\mathrm{GA}_{3}$ ve humik asit uygulamaları ile Narince 100 ppm $\mathrm{GA}_{3}$ de $1438 \mathrm{~kg} / \mathrm{da}$, Sultani Çekirdeksiz’de 500 ppm GA 3 de 390 kg yaprak toplanmıştır [36].

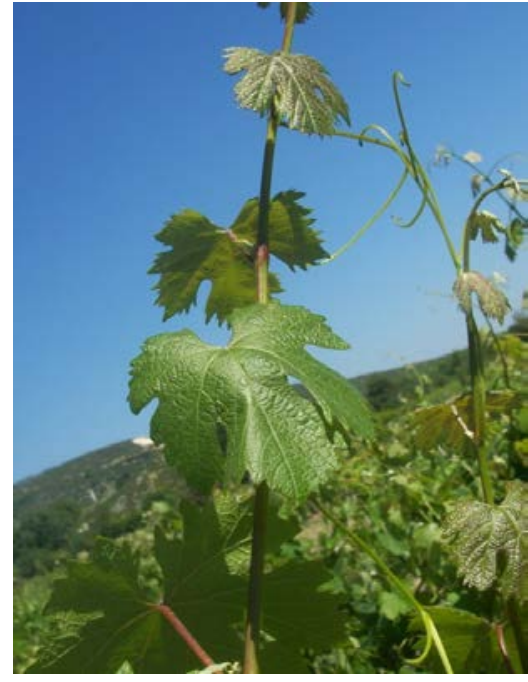

Şekil 1. Asmalarda salamuralık amaçla yaprak toplanan yazlık sürgün (Rüstem Cangi)

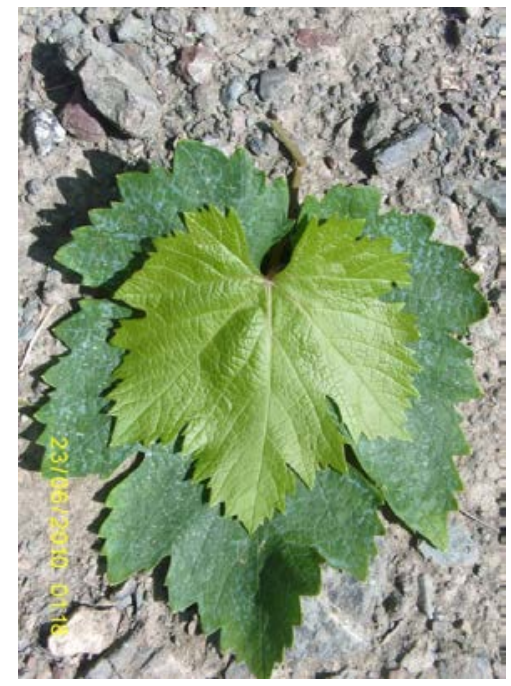

Şekil 2. Asmalardan toplanan sarma ve dolmalık yaprak ve olgun yaprağın görünüşü (Rüstem Cangi)

Kılıç [32], tarafından Erbaa ilçesinde iki yıl süre ile Narince çeşidinde yapılan çalışmada, goble omcalar 8 ve 12 göz/omca şeklinde, kordon şeklindeki asmalar ise 16-24 göz/omca şeklinde budanmıştır. Asmalara ayrıca dekara 7, 14 ve $21 \mathrm{~kg}$ azot uygulaması denenmiştir. Goble ve kordon terbiye sistemindeki asmalarda budama şiddeti ortalama verilerine göre asma yaprak verimi, goble omcalarda 389,7-417,6 g/omca arasında; kordon asmalarda ise 1178,8-1314 g/omca arasında değişmiştir. Azotlu 
gübre uygulaması yaprak verimini artırmıştır Ancak dekara $15 \mathrm{~kg}$ dan fazla net azot uygulanması, asma yapraklarında nitrat kalıntı miktarının MRL değerinin üstüne çıkmasına neden olmaktadır[41 ve 42].

\section{Asma Yapraklarının Salamuraya İşlenmesi ve Pazarlanması}

Bazı bölgelerde (Manisa) yapraklar salamura yapan firmalara taze olarak satılmakta; bazı bölgelerde (Tokat) ise üreticiler hasat ettikleri yaprakları salamura yaptıktan sonra değişik şekilde pazarlamaktadır.

İşleme ve muhafaza yöntemleri: Asmalardan toplanan taze asma yaprakları uzun süre dayanmadığı için, değişik yöntemlerle işlenerek diğer zamanlarda da tüketilebilmektedir. Asma yaprakları; salamuralı, salamurasız muhafaza yöntemleri dışında, kurutularak, tuzlu suda kaynatma, kuru tuzlama ve derin dondurucuda dondurularak saklanması gibi metotlarla da muhafaza edilmektedir [34].

Asma yaprağının salamura yapılması: Taze asma yaprağında bulunan karbonhidrat, protein ve diğer organik maddelerin mikroorganizmalar ve özellikle laktik asit bakterileri tarafindan biyokimyasal değişime uğratılması ile elde edilen fermente bir üründür. Tuz ve su gibi kolay ulaşılabilir maddelerle hazırlanışı ve minimum makine ekipman gereksinimi ile kolay ve düşük maliyetli bir işleme yöntemi olması sebebiyle Anadolu'da asma yaprağına uygulanan en eski ve en yaygın koruma ve saklama yöntemidir. Ticari üretim yapan firmalar tarafindan vakum ambalajlama ile paketlenip satışa sunulması, salamura asma yaprağının neredeyse tüm marketlerin raflarında yer bulmasını ve tüketicinin bu ürüne daha rahat ulaşmasını sağlamıştır[34 ve 35].

Tokat yöresinde asma yapraklarının salamura yöntemi: Sıcak salamura yapılacak yapraklar destelendikten sonra, plastik veya paslanmaz çelik kaplar içerisine, yaprak aya üst kısmı kapların dibine gelecek şekilde düzgün bir şekilde dizilir. Kapların üst kısmından $10 \mathrm{~cm}$ 'lik mesafe kalıncaya kadar yapraklar basılır. Yapraklar üst kısma kadar dizildiği zaman tülbent, çuval, pamuktan yapılmış temiz örtü ile kapatılır. Ağırlık yapan bir materyal veya kapların üst kısmına çapraz gelecek şekilde tahta vb malzeme ile yapraklar aşağıya bastırılır. Kabın aldığı su miktarı ve yaprak miktarı dikkate alınarak \%10 oranında tuz tartılarak hazırlanır ve tuzun yarısı kabın üst kısmına konur. $90-100{ }^{\circ} \mathrm{C}$ sıcaklıktaki su kaba üstten ilave edilir. Sıcak su ilave edilirken asma yapraklarına direkt olarak temas etmesi yaprakların esmerleşmesine ve renginin koyulaşmasına neden olmaktadır. Bu ise kaliteyi düşürmektedir. Bu nedenle yaprakların üstüne serilen tülbent veya bez vb malzemeler örtülmekte suyun yapraklara direkt teması önlenmektedir. Salamura kabının üst kısmına su ulaştığında tuzun geri kalan kısmı ilave edilmektedir. Yaprak 24 saat içerisinde salamura yapılmış olur. Kap içerisinde salamura yapraklar 8-10 gün muhafaza edilebilir. Daha fazla bekletildiğinde, saklama ve ortam koşullarına göre kapların üst kısmında zar, mantar, küf ve maya gibi gıda güvenliği açısından tehlike yaratan oluşumlar görülmektedir [43]. Uzun süre salamura su içerisinde bekleyen yapraklara, salamurada oluşan kötü koku sirayet etmekte ve kaliteyi düşürmektedir. $\mathrm{Bu}$ nedenle en geç 1 hafta içerisinde salamura yapraklar ya satılacakları kaplara ambalajlanmakta, ya da hijyenik büyük kaplara (20-50 kg’llk) aktarılarak satı̧a sunulacakları ambalajlama işlemine kadar muhafaza edilmektedir. Hemen satılacak yapraklar, salamuradan çıkarıldıktan sonra salamura suları süzülür. Ambalajın ebat ve özelliğine göre demetler halinde katlanarak dizilirler ve kendi salamura suları ile tamamlanırlar. Ambalaj kaplarına kendi salamura suyu yeterli olmazsa, \%10 tuz içeren salamura suyu hazırlanarak ilaveten kullanılabilir. Tokat ilinde salamura 
yapraklar, demetler arasına tuz ilave edildikten sonra, 3-5 kg' lik plastik bidonlara basılarak salamura suyu ilave edilmeden de muhafaza edilmektedir.

Asma yaprağının konserve yapılması: Taze asma yaprağının bir takım ön işlemlerden (yıkama, ayıklama, haşlama, soğutma) sonra teneke kutu, cam kavanoz veya uygun özellikteki kaplara doldurulması, kapların hava almayacak şekilde (hermetik) kapatılması ve 1sıl işlem uygulaması suretiyle dayanıklı hale getirilmesidir. Uygulanacak ısıl işlemin sıcaklık ve süresi, ürünün asitlik düzeyi ve pH değeri ile doğrudan ilişkilidir. Yapraklar kaplara dolum yapıldıktan sonra üzerine dolgu sıvısı olarak ilave edilen, tuz ve sitrik asitle hazırlanmış salamuranın da etkisiyle ürünün asitlik düzeyi pH 4.5 'in altında kaldığı için pastörizasyon işlemiyle istenilen steriliteye ulaşılmakta ve asma yaprakları dayanıklı hale getirilmektedir [15, 34, 35].

Salamurasız yaprak muhafazası: Taze yaprakların doğrudan kavanozlara veya PET şişelere sıkıca doldurulup hava almayacak şekilde kapatılması yöntemidir. Bu sayede asma yaprakları, basit ve pratik bir şekilde yıl boyunca muhafaza edilebilmektedir. Bu yöntemle muhafazada, su buharı ve gaz geçirgenliği oldukça düşük olan ambalajın içerisindeki taze asma yapraklarında solunum devam etmekte, ambalaj içerisindeki gaz kompozisyonu zamanla değişmektedir. Solunumla oksijen azaldığı için asma yapraklarında mikrobiyal gelişme baskılanırken, yaprak rengi parlak yeşilden, zeytin sarısı renge dönüşmektedir. Tuz içermemesi nedeniyle tansiyon hastalarınca rahatlıkla tüketilebilmesi, çok fazla yatırıma gerek olmayışı ve atık salamura ile çevre kirliliğine yol açmaması, salamura yaprağa kıyasla avantajlı yönüdür [34].

Ülkemizde asma yaprağını tüketen vatandaşlarımızın daha güvenli gıda tüketmesi, ihracatta sürdürülebilir bir pazarlama için gıda güvenliği açısından üretim ve işleme aşamasında kalite standartlarının oluşturulması şarttır. Salamuralık asma yaprağı üretiminin yoğun olduğu bölgelerde üreticilerin bilgilendirilmesi dışında, gerekli kontrollerin düzenli bir şekilde yapılması, kalıntısız yaprakların daha iyi bedelle fiyatlandırılması bu konuda faydalı olacaktır. İyi tarım uygulaması ile yaprak üretimi yapacak üreticilerin firmalarla sözleşmeli üretim için yönlendirilmesi çözümlerden birisi olacaktır.

\section{Kaynaklar}

[1] TUIK, “Bitkisel Üretim İstatistikleri” www.tuik.gov.tr/PreTablo.do?alt_id=1001, 2017

[2] Yavaş İ., Fidan Y., “Üzüm Değerlendirme Şekillerinin İnsan Sağlı̆̆ı Yönünden Önemi” Gıda Sanayinin Sorunlarl ve Serbest Bölgenin Gida Sanayine Beklenen Etkileri Sempozyumu. 216221., Adana, 1986

[3] Anonim, http://manisaolay.com/haber-150-Muthis-bir-proje!.html (erişim 05/01/ 2012),2011a

[4] Anonim, http://www.tazeyaprak.com/index.php?do=dynamic/view\&pid=7(Erişim 05/01/2012), $2011 b$

[5] Yerasimos, M., “500 years of Ottoman cuisine [500 y1llık Osmanlı mutfağ1]” Istanbul: Boyut; 2002

[6] Doğan Y., ,Nedelcheva A., Łuczaj Ł., Drăgulescu C., Stefkov G., Maglajlić A., Ferrier J., Papp N., Hajdari A., Mustafa B., Dajić-Stevanović Z. ve Pieroni A., “The Importance of a Leaf: The 
Ethnobotany of sarma in Turkey and The Balkans” Journal of Ethnobiology and Ethnomedicine, 11, 26, 2015

[7] Downton W.J.S., Grant W.J.R., Loveys B.R., "Diurnal Changes in the Photosynthesis of FieldGrown Grapevines” New Phyto. 105, 71-80., 1987

[8] Roper T.R., Williams,, L.E., "Net $\mathrm{CO}_{2}$ Assimilation and Carbohydrate Partitioning of Grapevine Leaves In Response to Trunk Girdling and Gibberellic Acid Application” Plant Physiology, 89, 1136-40, 1989

[9] Kliewer, W.M., “Grapevine Physiology”. Leaflet 21231. Division of Agricultural Sciences University of California, 1981

[10] Ribereau G.J., Reynold E., “Science et Techniques de la Vigne.Tome 1” Biologie de la Vigne. Sols de Vignobles.Ed. Dunod. Paris., 1971

[11] El Nehir S., Kavas A., Karakaya S., "Nutrient Composition of Stuffed Vine Leaves: A Mediterranean Diatery” Journal of Food Quality, 20, 337- 341, 1997

[12] Anonim 2015a. Bağ Yaprağı Alım Fiyatı Üreticileri Sevindirdi http://www.haberler.com/bagyapragi-alim-fiyati-ureticileri-sevindirdi-7483396-haberi/(Erișim:20/12/2016)

[13] Yağcı A., Cangi R., Topçu N., Sucu S., Kılıç D., “Tokat’ta Kırsal Kalkınmaya Alternatif Üretim Modeli "Yüksek Rakımlı Bölgelerde Organik Salamuralık Asma Yaprak Üretimi” 1. Ulusal Tokat Sempozyumu, 01-03 Kasım, Cilt: II, sayfa 65-70, Tokat, 2012

[14] Çelik H., “Türkiye Bağcılığında Üretim Hedefleri” Vizyon 2023 Bağcılık Çalıştayı, 26-27 Haziran, Tekirdağ Bağcılık Araş.Enstitüsü, Tekirdağ, 2013

[15] Göktürk. N., Artık N., Yavaş İ., Fidan Y., "Bazı Üzüm Çeşitleri ve Asma Anacı Yapraklarının Yaprak Konservesi Olarak Değerlendirilme Olanakları Üzerinde Bir Araştırma” Gıda, 22 (1),1523, 1997

[16] Ağaoğlu Y.S., Yazgan A., Kara Z., “Tokat yöresinde Yaprak Salamuracılı̆̆ına Yönelik Asma Yetiştiriciliği Üzerinde Bir Araştırma” Türkiye II. Bağcılık Sempozyumu, Bursa, 1988

[17] Çelik H., Kunter B., Söylemezoğlu G., Ergül A., Çelik H., Karataş H., Özdemir G., Atak A., “Bağcılığın Geliştirilmesi Yöntemleri ve Üretim Hedefleri” TZM VII. Teknik Kongresi 11-15 Ocak, 2010. Ankara 493-513.s (Erişim: 05/01/2012), 2012

[18] Gülcü M., "Traditional Grape Products of Thracian Region and Local Production Form in Turkey” 33 rd World Congress of Vine and Wine, 20-25 June Tbilisi, Georgia, 2010

[19] Anonim, http://www.haberler.com/uzumden-once-yapragi-kazandiriyor-2716637-haberi/ (Erişim: 05/12/2011), 2011c

[20] Anonim, http://www.milliyet.com.tr/Ekonomi/SonDakika.aspx?aType=Son Dakika\&ArticleID =989387\&Date=10.09.2008\&Kategori=ekonomi \&b=Pazarda20yaprak\%20satan\%20kardesler, $\%$ 20birikimleri\%20ile\%20fabrika\%20kurdu, 2011d

[21] Ölmez Cangi S., Cangi R., Kılıç D., Bekar T., “Salamuralık Asma Yaprağının Dolu Zararına Karşı Sigortalanmasında Ekspertiz Rapor Parametrelerinin Belirlenmesi” Tarım Bilimleri Araştırma Dergisi, 9 (1), 37-44, 2016

[22] Anonim,. http://insanvehayat.com/erbaa-bag-yapragi/ (Erişim:20/12/216), 2016a 
[23] Cangi R., Kaya C., Kılıç D., Yıldız M., “Tokat Yöresinde Salamuralık Asma Yaprak Üretimi, Hasad ve İşlemede Karşılaşılan Sorunlar ve Çözüm Önerileri” 6. Ulusal Bağcılık Sempozyumu, 19-23 Eylül, Bildiri Kitabı, Cilt:2, 632-640, Tekirdağ, 2005

[24] Kılıç D., Cangi R., Kaya C., “Tokat’ta Üzümün Değerlendirilmesi ve Üzümden Elde Edilen Ürünler” 5. Ulusal Bahçe Bitkileri Kongresi, 4-7 Eylül, Cilt 2: 345-348, Erzurum, 2007

[25] Ertürk A., “Tekirdağ İlinde Yetiştirilen Yapıncak Üzüm Çeşidinin Yapraklarında Salamura Öncesi ve Sonrası Fungisit Kalıntı Miktarı” NKÜ. Fen Bil. Enstitüsü, Tekirdağ, 29 s., 2009

[26] Cangi R., Yanar Y., Yağcı A., Topçu N., Sucu S., Dülgeroğlu D., "Narince Üzüm Çeşidinin Yapraklarında Farklı Fungusit Uygulamaları ve Salamura Yöntemlerine Bağlı Olarak Fungusit Kalıntı Düzeylerinin Belirlenmesi” JAFAG, 31 (2), 2013

[27] Yanar Y., Cangi R., Özata K., “Tokat Yöresinde Üretilen Salamuralık Asma Yapraklarında Pestisit Kalıntı Düzeylerinin Belirlenmesi” 8. Băgcllık ve Tekn. Sem., 25-28 Eylül, 267-275 s.Konya, 2013.

[28] Anonim, http://www.apelasyon.com/Yazi/329-yaprak-sarma(Erişim:20/12/216), 2016 b

[29] Anonim, http://www.iib.org.tr/tr/diger-duyurular-avrupa-birligine-asma-yapragi-ihracati.html (Erişim:20/12/216), 2016c

[30] Benmayor, G., “Sarma Savaşı” http://cep.hurriyet.com.tr/yazarlar/27097604 (Erişim:20/12/2016), 2016d

[31] Cangi R. ve Yağcı A., "Salamuralık Asma Yaprağı Üretimi” Kırsal Kalkınma Dergisi, 5, 22-23, 2016

[32] Kılıç D., "Narince Üzüm Çeşidinde Farklı Budama Seviyesi ve Azot Dozlarının Salamuralık Asma Yaprak Verimi ve Kalitesi Üzerine Etkileri” GOÜ Fen Bilimleri Ens., Yük. Lis. Tezi, 87 s., 2007

[33] Çelik H., Ağaoğlu Y.S., Fidan Y., Marasalı B., Söylemezoğlu G., “Genel Bağcılık” Sun Fidan A.Ş., Mesleki Kitaplar Serisi:1. Fersa Matbaacılık San. ve Tic. Ltd. Şti., Ankara, 253 s., 1998

[34] Gülcü M. ve Torçuk A.İ., "Yemeklik Asma Yaprağı Üretimi ve Pazarlamasında Kalite Parametreleri” Meyve Bilimi, 1, 75-79, 2016

[35] Sat I. G., Sengul M., Keles F., "Use of Grape Leaves in Canned Food”, Pakistan Journal of Nutrition, 1(6), 257-262, 2002

[36] Demirhan Y., "Narince ve Sultani Çekirdekdiz Üzüm Çeşitlerinden Salamuralık Asma Yaprağ1 Üretimine Gibberellik Asit ve Hümik Asit Uygulamalarının Etkileri” Yüksek Lisans Tezi. Selçuk Ünv. .Fen Bilimleri Enstitüsü Bahçe Bitkileri A.B.D, Yüksek. Lisans tezi, 73 s, Konya., 2006

[37] Anonim, http://www.hurriyet.com.tr/asiri-yaprak-toplama-uzumu-dalinda-kuruttu-37301975 (Erişim:20/12/216), 2016e

[38] Anonim, http://www.hurriyet.com.tr/asma-yapragini-toplayan-ureticilere-verim-kaybi-uyarisi37276101 (Erişim:20/12/216), 2016f.

[39] Elmalı Ö., “Tokat İli Merkez İlçede Bağcılıkla Uğraşan İşletmelerin Üretim ve Pazarlama Sorunları” YemeklikYyyGOÜ. Fen Bilimleri Enstitüsü Yüksek Lisans Tezi, 152 s., 2008 
[40] Bekar T., "Narince (Vitis Vinifera Spp.) Üzüm Çeşidinde Yaprak Hasat Sıklığı ve Salkım Seyreltmenin Meyve, Şıra ve Şarap Kalitesine Etkisi” GOÜ Fen Bilimleri Enstitüsü Doktora Tezi, Tokat, 2015

[41] Acar İ., "Farklı Azotlu Gübre Form ve Dozlarının Salamuralık Asma Yapraklarında Verim Ve Nitrat Birikimine Etkisi”, GOÜ Fen Bilimleri Enstitüsü Yüksek Lisans Tezi, 44 s., Tokat, 2013

[42] Erdem H., Acar İ., Cangi R., Yağcı A., Topçu N., Sucu S., “Tokat Yöresinde Üretilen Salamuralık Asma Yapraklarında Nitrat Kalıntı Düzeylerinin Belirlenmesi” 8. Băgcllı ve Teknolojileri Sempozyum, 25- 28 Eylül Konya, Selçuk Tarım ve Gıda Bilimleri Dergisi A , 27, 276-280, 2013

[43] Kocatepe D., Tırıl A., "Sağlıklı Beslenme ve Geleneksel Gıdalar (Healthy Nutrition and Traditional Foods)” Journal of Tourism and Gastronomy Studies, 55, 63., 2015 